\title{
Classroom learning of English L2 requests: Input and interactional opportunities in French secondary schools
}

Language Teaching Research

(C) The Author(s) 2021

Article reuse guidelines: sagepub.com/journals-permissions DOI: $|0.1| 77 /|362| 6882 \mid 1064932$ journals.sagepub.com/home/ltr

\author{
Aisha Siddiqa $1 D$ \\ ZHAW, Switzerland \\ Shona Whyte iD \\ Université Côte d'Azur, France
}

\begin{abstract}
With today's strong focus on communicative competence in second language (L2) classrooms, speech acts like suggestions, requests, refusals, and apologies are often investigated in interlanguage pragmatic (ILP) as well as instructional pragmatics. Even though there is strong evidence in ILP research that purports that L2 learners respond well to pragmatic instruction (Taguchi, 20I5), the teaching of L2 pragmatics is not always prioritized in textbooks, teaching programmes or teacher education (Barron, 2016; Savvidou \& Economidou-Kogetsidis, 2019) with the consequence that pragmatic learning can only occur incidentally. The present study examines opportunities to acquire L2 requests for 308 English as a foreign language (EFL) learners across 7 years of instruction in French secondary schools, investigating textbooks preferred by teachers, classroom interaction (39 hours), and teacher perspectives (semi-structured interviews with 10 teachers). After a pragmatic analysis of $15 \mathrm{EFL}$ textbooks with a focus on requests, the study examines the incidence of metapragmatic input in 39 hours of teaching in 13 classes at 3 levels, and relates interactional patterns with interview data from the 10 teachers concerned. Findings suggest limited pragmatic input in both textbooks and classroom interaction. By comparing the profiles of teachers who encouraged $L 2$ requests with those who did not, the study offers new explanations for $L 2$ learners' limited pragmatic development which also broadly corroborate previous findings of somewhat limited potential for L2 pragmatic development in obligatory school contexts.
\end{abstract}

\section{Keywords}

English as a foreign language, France, instructional pragmatics, interlanguage pragmatics, L2 requests, language education, textbooks

\section{Corresponding author:}

Aisha Siddiqa, Institute of Language Competence, School of Applied Linguistics, ZHAW, Theaterstrasse 17, Winterthur, 8400, Switzerland

Email: sidd@zhaw.ch 


\section{Introduction}

Three important developments have marked the course of second (L2) and foreign language (FL) education over the past 50 years or so: the cognitive revolution heralded in second language (L2) studies by Corder (1967) paved the way for the hugely influential communicative approach (Savignon, 1976) and the sociocultural turn (Firth \& Wagner, 2007; Wagner \& Firth, 1997) that was its logical extension. This interest in language acquisition, interaction, and use which underlies today's focus on communicative competence, considered by some 'the ultimate goal of language teaching' (Usó-Juan, 2008), places pragmatics at centre stage. Indeed over the past twenty years the CEFR (Common European Frame of Reference, Council of Europe, 2001) has brought an action-oriented language pedagogy into the majority of European language classrooms, including a recently reinforced concern for pragmatic learning (CEFR, Council of Europe, 2018).

Long considered the poor cousin of second language studies (Kasper, 1992; Kasper \& Rose, 2002), the importance and teachability of L2 pragmatics have been recognized in the past decade (Ishihara, 2010) leading to a strong body of research in both L2 and FL classrooms as well as study abroad contexts, where student learners have direct contact with the target culture over a pre-determined period of time (for an overview, see Taguchi, 2015). However, links between L2 pragmatic research and everyday classroom pedagogy remain elusive (Bardovi-Harlig, 2020; Sykes, 2013), especially in FL contexts outside university settings where much of this research is conducted. For this reason, the present study investigates the teaching of L2 pragmatics in secondary school language classrooms in France, using a cross-sectional design to investigate some 300 pupils at three distinct points in their learning: the start and finish of lower secondary schooling (ages 11 and 15) and the end of upper secondary (age 18). Part of a larger research project (Siddiqa, 2018) which replicated a study of young English as a foreign language (EFL) learners in Taiwan (Rose, 2009), the present article considers the influence of textbooks and teacher attitudes on opportunities for L2 pragmatic development in L2 English requests by young francophone learners. We begin with a review of recent research in instructional pragmatics, before outlining the textbook analysis, classroom filming, and teacher interviews. In Section VI, a detailed investigation of L2 learner requests occurring in classroom interaction reveals the influence of teachers' pedagogical understanding and priorities on opportunities for pragmatic learning.

\section{Literature review}

A relatively young field of inquiry, second language (L2) pragmatics has grown exponentially over the past two decades and now boasts several sub-disciplines, including interlanguage pragmatics (ILP), cross-cultural pragmatics, as well as our focus here: instructional pragmatics (Ishihara, 2010; Sykes, 2020; Taguchi, 2015). In contrast to early L2 pragmatic research which focused on comparisons with first language (L1) norms, and on use rather than acquisition or development of pragmatic skills (Kasper, 1997; Martínez-Flor et al., 2003; Rose \& Kasper, 2002), instructional pragmatics addresses questions of teachability and learnability in line with Schmidt's (1993) noticing hypothesis. Studies have examined the effects of different types of instructional 
interventions, sometimes in comparison with simple exposure (Bardovi-Harlig, 2001; Rose, 2005); comprehensive overviews by Taguchi (2015), McConachy (2017) and Cohen (2018) provide convincing evidence for the role of instruction in developing L2 pragmatic competence. This competence is clearly amenable to instruction and learners who are given instructional support perform better than uninstructed peers (BardoviHarlig \& Griffin, 2005; Bardovi-Harlig \& Mahan-Taylor, 2003). L2 pragmatic learning can not only be supported in study abroad contexts (Blood, 2018; Glaser, 2017; Hassall, 2013; Hernandez, 2010; Hernandez \& Boero, 2018; Nguyen \& Le Ho, 2018; Shively, 2011) but also in FL classrooms (Ishihara, 2010; Taguchi, 2015), previously considered less propitious sites for pragmatic development. Taguchi (2018) links the newer FL instructional research to a shift in analytical focus from 'pragmatics-within-individuals' to 'pragmatics in interaction in context,' leading to an interest in conversational analysis (CA) and discursive approaches to investigating naturalistic data. In research on pragmatic instruction on requests and refusals with L1 Arabic learners of English, Al-Gahtani and Roever $(2013,2018)$ used fine-grained CA to show gradual development in L2 learners' refusals at different proficiency levels with a wider range of interactional and mitigation tools (e.g. solidarity terms, pre-explanations, expressions of regret), although gaps remain even in advanced learners' refusal production. Therefore, there is a general consensus that pragmatics should be included in classroom pedagogy like other L2 skills such as grammar and lexis.

There remains debate as to the most effective type of instructional intervention to support L2 pragmatic development, with different studies comparing explicit and implicit teaching (Alcón Soler, 2007; Derakhshan \& Eslami, 2020; Tateyama, 2001), and inductive versus deductive approaches (e.g. Martínez-Flor, 2008). Early research suggested an advantage for explicit methods: Koike and Pearson (2005) compared explicit and implicit teaching of L2 Spanish suggestions, for example, while Félix-Brasdefer (2008) investigated lexical and syntactic mitigators in refusals. In both cases explicit instruction resulted in greater, more durable learning gains. However, a recent meta-analysis by Taguchi $(2015$, p. 11) showed that 'the implicit approach can be just as effective in causing changes in learners' pragmatic systems' by encouraging awareness of form-functioncontext mappings which can 'lead to learning, with or without direct explanation' (Taguchi, 2015, p. 12).

Two major longstanding challenges to effective L2 pragmatic instruction remain the absence of suitable teaching materials and lack of teacher training (Bardovi-Harlig, 2001; Bardovi-Harlig \& Hartford, 2005). Cohen and Ishihara (2013, p. 13) note that 'pragmatics is often neglected or only marginally treated in L2 curricula' and call for 'further materials development [to] support teachers in preparing learners to understand and use language effectively in context and to express their own voice as they wish in the target community'. Regarding materials development, Sykes (2017) reports on one solution to the problem: the creation of online repositories for sharing and exchanging materials internationally. Despite initial positive results (Cohen \& Sykes, 2012; Taguchi \& Sykes, 2013), the technology-mediated teaching and learning of L2 pragmatics is made more complex by the necessary inclusion of a 'transnational perspective' involving teachers in a range of different contexts around the world (Sykes, 2017, p. 122). For many FL contexts, however, school teachers often rely on textbooks for reasons of 
convenience (Baleghizadeh \& Rastin, 2015; Crawford, 2002) and authority (Arva \& Medgyes, 2000).

A number of pragmatic analyses of FL textbooks point to certain limitations for the teaching of L2 pragmatics. An early study of 8 leading ESL (English as a second language) and EFL textbooks and teacher's manuals used in US universities, Vellenga (2004) found that only approximately $20 \%$ of pages contained pragmatic information, and this constituted neither 'a pragmatically appropriate source of linguistic input nor explicit metapragmatic information' (paragraph 24). A more recent study of 10 EFL textbooks commonly used with non-English majors at B1 level in China found similarly limited pragmatic information (17\%), with little metapragmatic input or intralingual variation (Ren \& Han, 2016). Several studies of secondary school EFL textbooks have focused on Germany. Limberg (2015) provides a comprehensive overview of the speech act of apologizing, showing areas of difficulty for L2 learners and sketching an ideal instructional progression. He claims textbooks in the past 'have been criticized for their cursory treatment of pragmatic phenomena' showing weaknesses regarding metalinguistic information and sociopragmatic features (see also Barron, 2007; Ogiermann, 2010; Syrbe \& Rose, 2016). Barron (2016) provides a thorough pragmatic analysis of an EFL textbook series using Cross-Cultural Speech Act Research Project (CCSARP) coding of requests (Blum-Kulka, House \& Kasper, 1989). Findings showed that the range of request strategies and types of modification in textbook examples was limited and failed to address areas of potential negative L1 transfer. For example, 'please' was treated as an illocutionary force indicating device and a mitigator, without discussion of non-standard requests where its misuse upgraded the imposition rather than downgrading or softening it (Barron, 2016, p. 2176). In her conclusion Barron (2016) challenges publishers to remedy the situation for learners - 'we await future developments.' Limberg (2015, p. 16), on the other hand, places the onus on teachers: 'Teachers have to realize and address this properly.'

Indeed, Celce-Murcia (2008) expresses concerns with respect to language teacher preparation in pragmatics. She equates pragmatic knowledge with the sociocultural dimension of communicative competence, highlighting both the relative importance of a 'social or cultural blunder' compared to a simple linguistic error, and the fact that 'second and foreign language teachers typically have far greater awareness and knowledge of linguistic rules than they do of the sociocultural behaviors and expectations that accompany use of the target language' (Celce-Murcia, 2008, p. 46). Teachers' attitudes and beliefs are formed during their own language learning experiences and from training and teaching experience, and affect pedagogical choices in the classroom (Borg, 2009, 2015). Indeed Vellenga (2004) supplemented her textbook analysis with interviews with 4 teachers and concluded 'even professional teachers rarely have the time, inclination, or training to include supplementary pragmatic information in their lessons.'

Savvidou and Economidou-Kogetsidis (2019, p. 41) confirm that: 'unlike L2 grammatical errors that are easily recognizable by non-linguists as the result of one's linguistic deficiency, the source of pragmatic failures is not easily recognized by hearers, and speakers are more harshly judged.' They interviewed 10 Greek and Cypriot teachers of EFL in private schools in Cyprus, and found teachers to lack theoretical knowledge of pragmatics, and although the teachers saw its 'intrinsic value', they claimed to have no time or expertise to address pragmatics within curricular constraints. In another study examining actual classroom practice, Szczepaniak-Kozak and Wąsikiewicz-Firlej (2018) 
compared 2 lessons by each of 2 Polish and 2 American teachers of small business English classes in a private school in Poland. They found the Polish teachers used a wider range of request strategies which they imputed to active pedagogy derived from more extensive teacher training and teaching experience. They conclude that 'the routine and limited repertoire of teacher talk causes impoverished language input in the classroom in general' (p. 139) and call for greater teacher awareness of this consequence.

As shown in the above discussion, research in instructional pragmatics and ILP in general has addressed the teachability concern by investigating methods, materials, and teacher education. Studies show that L2 pragmatics can be taught both explicitly and implicitly, but that materials tend neither to be abundantly available nor generally very accurate. The present study seeks to test these findings in an understudied yet very important context, the obligatory secondary school FL classroom. Our investigation includes consideration of teaching materials, classroom practice, and teacher education in a single study, in order to examine the whole context for the development of L2 pragmatic competence among pupils. For this reason, we include a textbook analysis, an investigation of classroom interaction, and an examination of teacher perceptions about L2 pragmatics. Requests were chosen as the main focus of study because of their common occurrence in classroom settings as well as their central position in previous L2 pragmatic research (Achiba, 2003).

Following Searle (1976), this study classifies a request as a directive act which is an attempt 'by the speaker to get the hearer to do something' (p. 11). Since requests usually make the hearer do something for the speaker (as a favour), they may come across as face-threatening and may require attenuation to soften the imposition of the request (Brown \& Levinson, 1987). Given the frequency of occurrence of requests in our daily life, it is important to master this important speech act to maintain healthy social relations and to avoid cross-cultural misunderstandings.

\section{Research questions}

The questions this article investigates are the following:

1. How are L2 English requests treated in textbooks used in secondary school EFL classes in France?

a. Are requests presented explicitly and/or do they occur implicitly or incidentally in French secondary textbooks?

b. What type of requests are presented: what levels of directness are shown and what kind of metapragmatic input is provided?

2. What opportunities for L2 English requests arise in secondary school classes?

a. What kind of requests occur in English in classroom settings?

b. What support do teachers offer to encourage pupils to make requests?

3. What are teachers' beliefs and objectives with respect to textbooks and L2 pragmatic instruction?

a. How are these beliefs expressed in video-stimulated recall interviews?

b. How do they affect opportunities to make L2 requests in classroom interaction? 
Table I. Teacher profiles.

\begin{tabular}{lllll}
\hline Name & Level & $\begin{array}{l}\text { Age } \\
\text { (years) }\end{array}$ & $\begin{array}{l}\text { Experience } \\
\text { (years) }\end{array}$ & Language profile \\
\hline Alice & 1 & $4 I-44$ & $15-20$ & French \\
Birgit & 1 & $35-40$ & $0-5$ & Norwegian \\
Candice & 1 & $31-34$ & $6-10$ & French \\
Danièle & $1+2$ & $25-30$ & $0-5$ & French \\
Eva & $1+2$ & $35-40$ & $6-10$ & French \\
Fanny & 2 & $31-34$ & $6-10$ & French, I year teaching assistant UK \\
Giselle & 3 & $51+$ & $21-24$ & French, 2 years' teaching USA \\
Hélène & 3 & $35-40$ & $6-10$ & French \\
Irène & $3+3$ & $45-50$ & $21-24$ & American \\
Julie & 3 & $45-50$ & $6-10$ & Italian, UK residence \\
\hline
\end{tabular}

\section{Method}

Part of a larger investigation of L2 requests among EFL classroom learners in France (Siddiqa, 2018), the present study employed a cross-sectional design including teachers and learners at three levels of secondary education, and examined textbooks, classroom practice, and teacher attitudes and beliefs in relation to pragmatic instruction. Informed consent was obtained from pupils, parents, teachers, and schools, and data were collected over a five-month period towards the end of the school year.

\section{Participants}

The learners were 308 pupils in 13 intact EFL classes in 10 state secondary schools in an urban region of France. Five classes were at first year of lower secondary (Level 1; 131 pupils aged 11-12 years), three in the final year of lower secondary (Level 2; 73 pupils aged 14-15 years) and five in their final year of upper secondary school (Level 3; 104 pupils aged 17-18 years). In a demographic questionnaire, most learners reported 4-6 years of English at primary school with an L2 experience generally limited to the classroom: while two thirds of intermediate and advanced learners reported occasionally watching films or series in English, no pupil at any level had spent more than four weeks in English immersion, less than one quarter of participants read in English for pleasure, and only $15 \%$ reported an English-speaking parent.

Details of the 10 teachers are given in Table 1. In France, teacher education starts at graduate level, with the majority of teachers taking an undergraduate degree in the target language (English studies), followed by competitive teacher entrance exams which test literary and cultural knowledge, written and oral proficiency, and mastery of the institutional framework governing secondary education. Teaching follows prescribed national programmes based on the CEFR and leading to national exams at the end of lower and upper secondary school cycles, and teachers receive in-service training and inspections by a nationally appointed local inspectorate. Pedagogical practice tends to focus on whole-class, teacher-led activities with an emphasis on accuracy. Table 1 shows that the 
more experienced teachers in our study generally taught upper levels, as is often the case in French secondary education.

\section{Materials}

Four instruments were designed to elicit data:

- survey of textbook use administered online;

- a background questionnaire for teachers covering age, gender, teacher training, experience and attitudes;

- a set of questions to guide semi-structured video-stimulated recall interviews with respect to classroom activities, textbooks, and L2 pragmatics (see Appendix 1 in supplementary material).

- Classroom filming.

\section{Procedures}

Data on textbooks were collected via an online textbook survey involving 15 teachers in the authors' network from local lower $(n=8)$ and upper secondary schools $(n=7)$. This survey included 6 of the 10 teachers in our study, and served to identify 15 textbooks most frequently used in French secondary education. It also revealed that lower secondary teachers were more likely to use them regularly. These 15 textbooks were analysed for pragmatic information.

All 10 teachers in the study completed the background questionnaire and were asked to allow filming of lessons where there was the most interaction. Three one-hour sessions were videorecorded for each class over a period of approximately three weeks. All were videotaped and transcribed in order to identify and analyse any examples of L2 requests by teachers or learners, occurring either incidentally or as part of a planned activity. Additional learner data was collected via two controlled oral production tasks (i.e., cartoon oral production task, role plays) which are analysed in Siddiqa (2018). Following classroom filming, each teacher completed the background questionnaire followed by a 30-40 minute semi-structured interview with the first author to probe attitudes to textbooks and teaching pragmatics, and including video-stimulated recall with extracts from class films. Data were transcribed (Jefferson, 1984) for thematic analysis (Hadley, 2017).

\section{Analysis and discussion}

This section begins with a pragmatic analysis of the textbooks used in our secondary EFL context, before discussing classroom activities, and finally linking examples of classroom $\mathrm{L} 2$ requests to the teacher profiles developed from interview data.

\section{Textbooks}

To answer our first research question concerning the type and frequency of textbook requests, the 15 textbooks commonly used in our French secondary school context were collected for a detailed page-by-page analysis to find metapragmatic input related to L2 
Table 2. Requests featured in secondary school textbooks by level and type (percentages in parentheses).

\begin{tabular}{|c|c|c|c|c|}
\hline \multirow[t]{2}{*}{ Title } & \multicolumn{4}{|c|}{ Activities with requests } \\
\hline & $\begin{array}{l}\text { Total number } \\
\text { of activities }\end{array}$ & $\begin{array}{l}\text { Focus on } \\
\text { requests }\end{array}$ & Incidental & Total \\
\hline \multicolumn{5}{|l|}{ Level I: } \\
\hline New Enjoy English & 203 & $12(6 \%)$ & $16(8 \%)$ & $28(14 \%)$ \\
\hline Welcome & 274 & $3(1 \%)$ & $19(7 \%)$ & $22(8 \%)$ \\
\hline Connect Anglais & 332 & $3(1 \%)$ & $5(2 \%)$ & $8(2 \%)$ \\
\hline New Step In & 197 & $10(5 \%)$ & $9(5 \%)$ & $19(10 \%)$ \\
\hline Making friends & 293 & $15(5 \%)$ & $16(5 \%)$ & $31(11 \%)$ \\
\hline Total & 1299 & $43(3 \%)$ & $65(5 \%)$ & $108(8 \%)$ \\
\hline \multicolumn{5}{|l|}{ Level 2: } \\
\hline Enjoy English & 145 & $5(3 \%)$ & $5(3 \%)$ & $10(7 \%)$ \\
\hline Step In & 199 & $3(2 \%)$ & $5(3 \%)$ & $8(4 \%)$ \\
\hline Join the team Anglais & 238 & $3(1 \%)$ & $9(4 \%)$ & $12(5 \%)$ \\
\hline Welcome & 186 & $2(1 \%)$ & $12(6 \%)$ & 14 (8\%) \\
\hline Connect Anglais & 194 & $3(2 \%)$ & $9(5 \%)$ & $12(6 \%)$ \\
\hline Total & 962 & $16(2 \%)$ & $40(4 \%)$ & $56(6 \%)$ \\
\hline \multicolumn{5}{|l|}{ Level 3: } \\
\hline Meeting Point & 485 & $2(1 \%)$ & II (2\%) & $13(3 \%)$ \\
\hline New Missions & 374 & I (0\%) & $6(2 \%)$ & 7 (2\%) \\
\hline Full impact Anglais & 341 & $3(1 \%)$ & $2(1 \%)$ & $5(1 \%)$ \\
\hline Password English & 330 & I (0\%) & $5(2 \%)$ & $6(2 \%)$ \\
\hline Project & 190 & I (I\%) & $10(5 \%)$ & II (6\%) \\
\hline Total & 1720 & $8(1 \%)$ & $34(2 \%)$ & $42(2 \%)$ \\
\hline
\end{tabular}

requests (Barron, 2016; Usó-Juan, 2008; Vellenga, 2004). For this purpose, we examined all activities, that is, all independent tasks in every chapter containing topic descriptions and explanations, numbered practice exercises and reading passages, audio transcripts, and grammar explanations. Two types of metapragmatic information were identified: (1) activities with a focus on requests either in the form of grammar presentation (e.g. use of 'can') or production activities (e.g. writing a letter to a friend to ask a favour), and (2) activities featuring incidental requests which were not central to the activity. The activities were coded by the first author, and $20 \%$ coded by the second author with an interrater reliability of $97.7 \%$ (Cohen's kappa $=.95$ ). Table 2 below displays the list of textbooks cited by our teachers with the total number of activities, followed by tallies and percentages for both types of request treatment.

This analysis reveals a low incidence of L2 requests in textbooks, particularly explicit treatment of requests, and decreasing with age/proficiency level. In order to further characterize the textbook requests and compare them with the requests produced by learners, we used an adaptation of the CCSARP framework (Siddiqa, 2018; Blum-Kulka et al., 1989) to classify request strategies: direct (e.g. 'Repeat please'), conventionally indirect (e.g. 'Can you repeat please?'), and nonconventionally indirect requests (e.g. 'Sorry?' as a hint to ask someone to repeat). Table 3 displays the number of such requests alongside 
Table 3. Distribution of request strategies identified in L2 textbooks at all levels.

\begin{tabular}{|c|c|c|c|c|c|c|c|c|}
\hline \multirow{2}{*}{$\begin{array}{l}\text { All activities } \\
\text { with requests }\end{array}$} & \multirow{2}{*}{$\begin{array}{l}\text { Exercises } \\
\text { on requests }\end{array}$} & \multirow{2}{*}{$\begin{array}{l}\text { Total } \\
\text { number of } \\
\text { requests }\end{array}$} & \multicolumn{6}{|c|}{ Request strategy distribution } \\
\hline & & & \multicolumn{2}{|c|}{ Direct } & \multicolumn{2}{|c|}{$\begin{array}{l}\text { Conventionally } \\
\text { indirect }\end{array}$} & \multicolumn{2}{|c|}{$\begin{array}{l}\text { Non- } \\
\text { conventionally } \\
\text { indirect }\end{array}$} \\
\hline 108 & 10 & 242 & 139 & $57 \%$ & 87 & $36 \%$ & 6 & $2 \%$ \\
\hline 56 & 0 & 106 & 67 & $63 \%$ & 37 & $35 \%$ & 2 & $2 \%$ \\
\hline 42 & 3 & 77 & 54 & $70 \%$ & 16 & $21 \%$ & 4 & $5 \%$ \\
\hline
\end{tabular}

the distribution of these requests by strategy at each level. Again, the first author did the initial coding and 20\% were re-coded by the second author (interrater agreement of $88 \%$, $97 \%$, and $84 \%$ with Cohen's kappa of .76, .94, .13 in direct, conventionally indirect and, nonconventionally indirect requests respectively.)

These results differ slightly from comparable analyses in other countries. Barron's (2016) analysis of German secondary school EFL textbooks revealed that only direct and conventionally indirect requests were found in the textbooks, with no examples of nonconventionally indirect request at any level. Moreover, only three out of nine subcategories of direct and indirect requests (Blum-Kulka et al., 1989) were presented showing limitations of the range of strategies to which students are exposed via textbooks. UsóJuan (2008) found an overwhelming preponderance of conventionally indirect strategies in English for tourism textbooks used in Spain, with only one example of a direct request and no nonconventionally indirect requests in five different books. Moreover, these studies also found limited sociopragmatic information in the textbooks and teachers' manuals as assessed by the metapragmatic input provided. The differences in our dataset may be due to the relatively small number of examples identified in quite large corpora, or indeed to the different target readerships for particular textbooks.

Concerning the type of input related to L2 requests in our dataset, as noted earlier, activities containing metapragmatic information on requests was limited overall (see Table 2) and mostly depended on the teachers to make the given request input salient for learners. However, 12 such activities were identified in which explicit metapragmatic input was provided either in the form of explanation of modal verbs (see Extract 1), or provision of sample expressions for making specific requests (see Extract 2).

\section{Extract 1}

\section{Can/can't}

On peut utiliser can ou can't pour parler de ce qui est [Can and can't are used to talk about what it is].

possible/permis [possible/allowed]

You can park here.

Pupils can have lunch at school.

Can I have a biscuit? impossible/interdit [impossible/

forbidden]

You can't turn left here!

Pupils can't eat in class!

No, you can't !

New Enjoy (level 1, p. 154) 


\section{Extract 2}

Impliquez-vous dans l'échange. [Engage in interaction]

Demandez poliment de répéter ou de préciser. [Ask politely for repetition or explanation]

I didn't catch what you said, could you please repeat your question? / Would you mind

repeating your question?

I'm not sure I understand what you mean, could you explain, please?

Password (level 3, p. 151)

Like Usó-Juan (2008), we found little or no contextual information regarding the effect of social factors such as the degree of imposition or the status of addressees on the choice of strategies or modifiers for making appropriate L2 requests. The only sociopragmatic variation in one instance was introduced at level 2 (see Extract 3 ) in the form of the difference between the use of 'can' and 'could', where 'could' was presented as a politer substitute for 'can'.

\section{Extract 3}

\section{[Potential uses of could/couldn't]}

Parler d'une chose possible/impossible au preterit [To talk about something that is possible/impossible using the simple past]

It was dark so I couldn't see his face.

Parler d'une possibilité atténuée [To talk about a remote possibility]

We could have a bushfire.

Faire une demande plus poli [To make a more polite request]

Could you open the window please?

Enjoy English (level 2, p. 154)

These data suggest the limited treatment of instructional pragmatics in the French secondary school EFL curriculum: while requests, as we have seen, are an important speech act in the FL classroom, few examples and even less explicit metapragmatic input on English requests is provided in the most commonly used textbooks. Perhaps not surprisingly, there was no correlation between the type of request strategy most commonly featured in textbooks, direct requests, and learners' preferred strategies elicited via our production tasks, which was conventionally indirect (Siddiqa, 2018).

In the following section we turn from input available to learners for pragmatic development in textbooks to output opportunities in the language class itself.

\section{Classroom films}

Table 4 displays an overview of all classes filmed for our analysis with a description of number of pupils, preferred textbooks, and the number of activities conducted during film recordings. We also include our assessment of each teacher's attitude to using textbooks, based on views expressed during interviews. As noted in Section IV, three regular lessons (50-60 minutes) were recorded with each class. In these lessons, teachers used 
Table 4. Overview of class films by pupils, textbooks, teacher attitudes and activities.

\begin{tabular}{|c|c|c|c|c|c|c|}
\hline & $\begin{array}{l}\text { Classes } \\
\text { (hours) }\end{array}$ & $\begin{array}{l}\text { Pupils } \\
\text { (n) }\end{array}$ & Textbook & $\begin{array}{l}\text { Teacher } \\
\text { attitude } \\
\text { towards } \\
\text { textbooks }\end{array}$ & $\begin{array}{l}\text { Total } \\
\text { classroom } \\
\text { activities in } \\
\text { three lessons }\end{array}$ & $\begin{array}{l}\text { Activities } \\
\text { planned to } \\
\text { teach L2 } \\
\text { pragmatics }\end{array}$ \\
\hline \multicolumn{7}{|l|}{ Level I: } \\
\hline Alice & 3 & 24 & New Enjoy & positive & 8 & 0 \\
\hline Birgit & 3 & 28 & New Enjoy & positive & 10 & 0 \\
\hline Candice & 3 & 23 & none & negative & 9 & 0 \\
\hline Danièle & 2 & 27 & New Enjoy & positive & 7 & 1 \\
\hline Eva & 3 & 29 & New Enjoy & positive & 12 & 0 \\
\hline Total & 14 & 131 & & & 46 & 1 \\
\hline \multicolumn{7}{|l|}{ Level 2: } \\
\hline Danièle & 3 & 26 & none & negative & 3 & 0 \\
\hline Eva & 3 & 23 & none & negative & 5 & 0 \\
\hline Fanny & 3 & 24 & $\begin{array}{l}\text { New Enjoy, New } \\
\text { Step In, New Bridges }\end{array}$ & neutral & 5 & 0 \\
\hline Total & 9 & 73 & & & 13 & 0 \\
\hline \multicolumn{7}{|l|}{ Level 3: } \\
\hline Giselle & 3 & 22 & Missions & positive & 6 & 0 \\
\hline Hélène & 4 & 19 & Password English & neutral & 5 & 0 \\
\hline Irène & 3 & 21 & On Target, Bridges & neutral & 3 & 0 \\
\hline Irène & 3 & 16 & $\begin{array}{l}\text { Meeting Point, Full } \\
\text { Impact }\end{array}$ & neutral & 4 & 0 \\
\hline Julie & 3 & 26 & $\begin{array}{l}\text { Meeting Point, } \\
\text { Missions }\end{array}$ & negative & 4 & 0 \\
\hline Total & 16 & 104 & & & 22 & 0 \\
\hline \multicolumn{7}{|l|}{ Overall: } \\
\hline & 39 & 308 & & & 81 & 1 \\
\hline
\end{tabular}

numerous types of classroom activities including guessing games, picture descriptions, reading comprehension, and learner presentations. As shown in Table 4, activities were shorter and more frequent at level 1, lasting on average between 15 and 20 minutes, and focused mostly on vocabulary, grammar, with a little focus on pronunciation and culture. At level 2, activities lasted longer, hence fewer activities, and there was more emphasis on culture, while level 3 showed an emphasis on grammar and vocabulary. Pragmatics was tackled as part of a planned activity only once, at level 1.

Other than planned input, some spontaneous examples of metapragmatic input on requests were found where teachers provided scaffolding or encouraged pupils to make correct requests in English. A typical example of such an input is shown in Extract 4 where a teacher elicits learner repair.

\section{Extract 4}

1 Teacher: Okay what fairy tale did you know Alice

2 Alice: J'ai pas compris 
3 Teacher: I ((gesturing to elicit English)) (2.0) ((shakes her head and signs no with hands))

$4 \quad$ (1.4 seconds) t'as pas compris (.) I

5 Pupil: Oh I I don't know

6 Teacher: Wait (.) okay Julie ((to Alice)) she's helping you

7 Julie: I don't know

8 Teacher: ((to Alice)) Can you repeat

9 Alice: ((showing discomfort in her voice)) J'ai pas entendu miss

10 Julie: I don't [know]

11 Teacher: [Say] Can you

12 Alice: ((to Julie)) Can you uh repeat ((the teacher nods))

13 Julie: Uh I don't know

(Danièle, level 1)

In this excerpt one learner is unable to respond to the teacher's open question (line 1) and cannot offer a repair in L2, and another learner tries to help by providing an appropriate response 'I don't know' (line 5) which the first learner does not catch (line 9). The teacher models the repair request she has taught the class, 'can you repeat?' (lines 8,11 ) and succeeds in eliciting repetition by the learner of her classmate's suggestion ('I don't know', line 10). This request is scaffolded by the teacher and collaboratively constructed by the two learners. This kind of exchange is an instance of metapragmatic input since the whole routine is instigated and closed by the teacher. Requests for an addressee to repeat were most common in our dataset, as befits an instructional context with a predominance of whole-class, teacher-fronted activities (Siddiqa, 2018).

The frequency of this type of exchanges in the 13 filmed classes is shown in Table 5. At level 1, there were on average 4 requests per hour, at level 2 only 2 , and at level 3 only 2.5. Spontaneous learner requests are distinguished from instances initiated by the teacher, with the latter considered as metapragmatic input (as in Extract 6).

The request tallies in Table 5 allow a three-way division of the group of 10 teachers. Three practitioners, Danièle, Eva and Irène, actively promoted learner request behaviour both by permitting at least 10 spontaneous interventions as well as offering metapragmatic input. Three other teachers, Birgit, Candice, and Giselle either provided metapragmatic input or frequent opportunities for spontaneous requests, while the remaining four teachers, Alice, Fanny, Hélène, and Julie neither encouraged many learner requests nor provided input on this speech act. Table 5 also gives the average score for each class on a cloze test used to check proficiency (Siddiqa, 2018) and shows that the classes with most metapragmatic input were those where pupils performed less well on this test. In what follows we seek to investigate what distinguishes teachers who allowed and exploited pragmatic episodes from their peers who did not, by examining these sequences in detail and relating them to teacher profiles developed from survey and interview data.

\section{L2 requests in classroom interaction: Teacher profiles}

To establish profiles of the teachers in our study, questionnaires and interview transcripts were analysed both in terms of responses to our specific questions concerning textbooks, their teaching philosophy, and views of pragmatics, and also using grounded theory to 
Table 5. Summary of teacher input on learner requests with cloze test scores per class.

\begin{tabular}{|c|c|c|c|c|}
\hline \multirow[t]{2}{*}{ Teacher } & \multirow{2}{*}{$\begin{array}{l}\text { Spontaneous } \\
\text { learner } \\
\text { requests }\end{array}$} & \multirow{2}{*}{$\begin{array}{l}\text { Spontaneous } \\
\text { teacher } \\
\text { input }\end{array}$} & \multicolumn{2}{|c|}{$\begin{array}{l}\text { Learner proficiency (Max = } \\
80)\end{array}$} \\
\hline & & & $\begin{array}{l}\text { Mean } \\
\text { score per } \\
\text { class }\end{array}$ & $\begin{array}{l}\text { Standard } \\
\text { deviation } \\
\text { per class }\end{array}$ \\
\hline \multicolumn{5}{|l|}{ Level I: } \\
\hline Alice & 3 & 0 & 7.176 & 4.186 \\
\hline Birgit & 27 & 0 & 8.392 & 6.373 \\
\hline Candice & 3 & 1 & 4.428 & 4.051 \\
\hline Danièle & 27 & 5 & 4.653 & 2.544 \\
\hline Eva & 2 & 0 & 14.03 & 9.387 \\
\hline Total & 62 & 4 & 8.153 & 6.998 \\
\hline \multicolumn{5}{|l|}{ Level 2: } \\
\hline Danièle & 2 & 0 & 18.115 & I5.229 \\
\hline Eva & 10 & 1 & 14.038 & 9.387 \\
\hline Fanny & 7 & 0 & 14.952 & $10.14 \mid$ \\
\hline Total & 19 & 1 & 15.753 & 11.96 \\
\hline \multicolumn{5}{|l|}{ Level 3: } \\
\hline Giselle & 1 & I & 52.307 & 22.178 \\
\hline Hélène & 7 & 0 & 66.888 & 7.0612 \\
\hline Irène & 12 & 1 & 37.176 & $|7.79|$ \\
\hline Irène & 11 & 1 & 24.769 & 12.826 \\
\hline Julie & 6 & 0 & 50.947 & I5.984 \\
\hline Total & 37 & 3 & 45.13 & 20.69 \\
\hline
\end{tabular}

allow other themes to arise from an emic perspective (Hadley, 2017). Since there is an overlap in lower secondary teachers, with two participants working at levels 1 and 2, we examine these teachers together before moving on to upper secondary (level 3) teachers.

a Classes at levels I and 2 with and without $L 2$ requests. In the lower secondary classes, metapragmatic input was provided by Candice, Danièle, and Eva, while spontaneous learner requests were frequent in the classes of Birgit, Danièle and Eva. In Alice and Fanny's classes there was no teacher input and fewer learner requests. Little difference in age or experience is apparent across this divide, though Alice was the oldest and the only teacher not to receive initial training in action-oriented or task-based methodology. Similarly, variation in attitude towards textbooks did not correlate with willingness to teach pragmatics (Table 4). Classes without request input were characterized by a predominance of teacher-centred activities, often with some disturbance due to restive pupil behaviour, limited learner participation, and use of L1. Alice and Fanny generally used direct requests in English ('sit down', 'turn around') and in interviews considered the observed lessons to be typical of their teaching.

Birgit and Eva both used a warm-up routine involving learner-learner questions, and Birgit observed: 'I ask the students to ask questions in English [so] there is quite a lot of 
speaking even though it's not necessarily the main activity of the lesson.' She expressed reluctance to plan open-ended pair and group activities, claiming that alternatives to highly structured activities were not possible since learners at this level 'didn't have enough vocabulary or the structures to produce anything by themselves' so 'it's difficult to do otherwise' (Birgit). Regarding the pairwork observed Birgit commented 'they didn't talk in English together [. . .] I think it's too ambitious. They can't, they won't do it.' However, spontaneous learner requests were frequent in her classes, although she allowed rather than exploited these instances, as in Extract 5, where several learners collaborate to produce an $\mathrm{L} 2$ request.

\section{Extract 5}

1 Teacher: . . go around in the forest (1.0) what do you do (1.4) ((to a pupil who is raising his hand)) Adam

2 Pupil A ((or Adam)): ((hesitates)) can I ((laughs while holding a rolled up paper in his hand))

3 Pupil B ((trying to help)): Can I go to the

4 Pupil C: Can I go to the bin (.) ben c'est bon

(1.0)

5 Teacher: Sorry

6 Pupil D: Can I go to

7 Pupil E: Can I [go to the bin]

8 Pupil D: $\quad$ [Can I go to the] bin ((pupil A just smiles))

9 Teacher ((walks towards pupil A)): Uh Adam no no no (.) now concentrate on the work (0.5) okay (3.0) concentrate on the work

(Birgit, level 1)

This example is interesting since it speaks to one theory which we entertained during the design of this study, that is, that in spite of the potential limitations of textbook activities and different teacher priorities, learners themselves might create opportunities for pragmatic development. This seemed especially likely in the area of L2 requests due to the very nature of power dynamics and social relations in the secondary school classroom: the teacher holds authority through her institutional role and greater L2 proficiency, and requests constitute one of a small number of permitted speech acts: in French classrooms at this level learners are expected to raise their hands for permission to speak or move around the classroom. Here we see a small group of learners encouraging one to resist getting down to work by asking permission to throw out a piece of paper. The teacher shuts down the exchange without validating the efforts of these learners to produce an appropriate L2 request - 'Adam no no no' (line 9). This episode is an unusual instance of a meaningful utterance produced collaboratively and appropriately yet not identified as a learning opportunity, perhaps due to the teacher's view described earlier that these learners lacked the proficiency to 'produce anything by themselves.'

In lower secondary classes which did provide metapragmatic input, both Candice and Danièle used a good deal of French to provide instructions. Candice delivered highly structured and largely teacher-fronted lessons, and used both direct and indirect requests 
in her lessons. L2 request-related input occurred in one of her classes in the form of her instruction to use the expression 'repeat please' during a role play activity where one learner had to draw a monster based on another learner's description of the monster. Eva used more English in her classes at both levels, explaining that 'I try not to speak French as much as I can' and this was not an observer effect ('it's not because you were there'). She had learners repeat expressions 'not only to correct pronunciation but to just make them participate and speak.' In a similar episode, Eva made a learner translate her French request to English, responding to the French utterance Je peux effacer le tableau? with 'Yes please, can I clean the board.'

In contrast, Danièle organized more pair and group activities at level 2. She was careful to have learners reformulate their L1 questions in English, as shown in Extract 6 above. Danièle commented: "[when] they say "est-que vous pouvez dire" [can you say] I just snap my fingers and they know they have to say "Miss can you give the English for

".' She added that level 1 learners found this practice appropriate and 'fun' while level 2 pupils were more resistant ('they think it's fake'). We return in Section VI to this negative perception by learners and teachers of the appropriateness of using English beyond actual teaching and learning content when a common L1 (French) is readily available and of course used throughout the rest of the school day.

Besides the spontaneous L2 request input mentioned above, Danièle offered the only planned activity in our dataset at level 1 involving requests during a grammar lesson on the simple past. The teacher set up a chain activity whereby learners provided a response to a gapfill-exercise and nominated a classmate using a request structure ('Juliette, can you do number 2?') to complete the next blank. Some 10 requests were made during this activity, and some are shown below.

\section{Extract 6}

1 Teacher: Write the correction (3.0) and don't forget the question mark (1.4) do you have your workbook (0.8) it's in your pocket (.) write your question (.) exercise six (.) page ninety one (3.2) Mary

((several pupils raise hands to be picked by Mary))

2 Mary: Uh Evan can I: (1.2) uh (1.1) can you (0.8) number two

3 Evan: Uh (.) because I walked to school

4 Teacher: very good very good pronunciation (0.6) uh: ((writes on the board)) c'est because (1.0) ((clears her throat)) (2.5) uh Evan

(5.0)

5 Evan: Uh (2.2) ((laughs hesitatingly and looks around for the next interested participant))

6 Teacher: You choose (.) you are the boss

7 Evan: Can you: three uh Julie

(Danièle, level 1)

This transcript suggests that this interrogative form, involving both a modal auxiliary and inversion is well beyond these learners' current productive competence (indeed it corresponds to the fourth of six levels of the L2 English development sequence for questions developed by Lightbown and Spada (2013)). Hesitation is apparent in Mary's first 
request (line 2), while in Evan's request (lines 5, 7) the main verb 'do' is missing, and even the necessary vocabulary ('three', line 7) is not readily available.

What is striking however is Danièle's persistence in scaffolding her learners each time a communicative need arises, as Extract 7 illustrates.

\section{Extract 7}

1 Teacher ((to a pupil who is raising his hand)): Max, you finished (.) Alicia

2 Alicia: Uh est-ce que je peux avoir un mouchoir

3 Teacher: uh (0.5) can I

$4 \quad$ Alicia: Can I the mouchoir (tissue)

5 Teacher: Have

6 Alicia: have the mouchoir (tissue)

7 Teacher: do you remember (0.5) it's a paper but it's a different type of paper (0.4) a ((signals to her nose))

8 Some pupils: Mouch-mouch ((laughter))

9 Teacher: A tissue

10 Another pupil: Uh okay

11 Teacher ((writes the word 'tissue' on the board)): Alicia (.) can you ask the question in English

12 Alicia: Teacher I can (0.5) I

(1.0)

13 Teacher: Can I ((explains using her hands))

14 Alicia: I

((Lisa, sitting next to Alicia, hands her a tissue paper))

15 Teacher: Thanks Lisa

Danièle's attitude to her learners' potential for participating in interaction in English is quite different from that expressed by Birgit above. She organized informal activities too, such as celebrating a learner's birthday and letting pupils mingle with each other and talk freely over the cake. At one event during one of the filmed sessions, learners made some indirect requests in English (e.g. 'I'm hungry' as a request to get a piece of cake) lending weight to this teacher's concern both to scaffold L2 production in classroom interaction and also provide opportunities for learners to speak spontaneously.

b Requests in classes at level 3. At level three metapragmatic input by teacher and spontaneous learner requests occurred frequently in three of the five classes taught by two of the four teachers in the study; thus we compare Giselle and Irène, in whose classes examples arose, with Hélène and Julie, where they didn't. At this level there was a clear difference in experience between the two pairs: Giselle and Irène each had over 20 years' teaching experience, and both were seasoned teacher educators (Table 1). Similarly in terms of attitude to textbooks, these two expressed positive or neutral views, whereas Hélène and Julie were neutral and negative (Table 4).

In the filmed lessons Hélène adopted a task-based approach with pair work and group work followed by class presentations as a strategy 'to help the students speak on the text and not just fill in grades or papers'. Her explicit objective was to encourage discussion 
and debate: 'I try as much as possible not to have a one-way classroom like just a teacher asking questions and the student answering back' and to use English throughout. In one class she instructed: 'No French no French. If you disagree, you disagree in English,' and indeed interactions in her class featured a good deal of disagreement. Even though she emphasized speaking in English in her classes, she raised a common question shared by other teachers about teaching pragmatics:

I don't really know how to teach pragmatics. I mean how you would, you know, find some activities for teaching it? I guess we take for granted that it will come in the way with the things we do in class.

For Julie, who taught the other level 3 class where no metapragmatic input was recorded, attention to pragmatics was considered at best a distraction from exam preparation, and at worst, equated with inaccurate language use and low pedagogical expectations:

The exam still requires them to be able to talk about Shakespeare and literature with literary terms and to analyse something in detail . . . pragmatics enables to be able to survive but I think that this is detrimental to the accuracy of the language. So sometimes he managed to ask for ice-cream but even if couldn't speak the language you can say 'ice-cream' to buy it, actually I'm not sure this is enough for especially high school students of English.

Julie's focus for this final year class was exclusively on preparation for the baccalaureate exams and her lessons provided techniques for analysing literary texts in terms of broad themes laid down in national FL curricula. Pupils' requests to the teacher mostly occurred in French and no attempt was made to ask them to reformulate in English.

Concerning the level 3 teachers whose classes did feature metapragmatic input, Giselle, like Julie, was concerned with exam preparation, using authentic materials to practice analysing literary and cultural examples according to the set themes. Her teaching philosophy focused on learner interaction: 'what they read or what they hear, everything in the classroom is a pretext to make them talk [. . .] the more they talk, the better it is.' The request input occurring in her class, Extract 8, is similar to Extract 4 above where the teacher attempts to elicit a short repair sequence, in this case while going over answers to a listening comprehension exercise.

\section{Extract 8}

1 Teacher: Okay what's the second question (11.4 seconds) vous vous souvenez de la question (0.8) nobody

(1.2)

2 A pupil to teacher: uh on remet

3 Teacher: ((nods and walks towards the board then stops and looks back signalling the pupil to repeat in English))

4 The pupil: Can you (1.6)

5 Teacher: Can you play it again

6 The pupil: Yes

(Giselle, level 3) 
Irène, an American trained in France, placed great emphasis on repetition as a pedagogical technique, modelling 'the same things over and over again until hopefully the weakest pupils can at least participate and repeat and get the meaning of somethings that have been already said in class.' For this teacher, the pupils 'are conditioned to be very passive learners. They expect the teacher to teach rather than asking their own questions that might really interest them.' Irène uses English most of the time, correcting pronunciation and grammar frequently. Extract 9 shows this teacher's strategy of having one pupil repeat another's utterance (line 4), and provides explicit metapragmatic information (line 5).

Extract 9

1 Teacher ((to Ben who is raising his hand)): Ben

2 Ben: uh: I can I can take your: your w/ book please

3 Teacher: >yeah but you don't need the book $<(0.3)>$ the book is not absolutely necessary $<$ we're (.) we're we're going to $(0.5)$ so INDEED Ben the question is can I

4 Ben: can I

5 Teacher: or may I if you are polite ( 0.3$)$ but in any case uh what we are going to do is to try to make sure that we understand (0.4) ONE HUNDRED percent of the answer (.)

The other example in Irène's teaching comes from an episode at the end of a lesson. As in Extract 7 at level 1, Extract 10 shows an extended scaffolding sequence where the teacher provides input on personal pronouns (his, your, our) and copula-pronoun inversion before giving permission for students to leave their bags in her classroom:

Extract 10

1 Clément (to teacher at the end of a class): Hi

2 Teacher: Hello

3 Clément: Hello if possible

4 Teacher: It is $(\mathbf{0 . 3})$ is it possible

5 Clément: Is it possible to uh: put uh: (0.4) your bag

6 Teacher: No (.) no (.) no (.) hi/ his bag and your bag is (0.8)

7 Pupil B: Uh je sais pas

8 Clément: C'est pas your (0.6)

9 Teacher: OUR

10 Clément: Our

11 Teacher: Bags

12 Clément: Bags

13 Teacher: Now REPEAT (0.4) uh [Clément]

14 Clément: [it's it] is

15 Teacher:

16 Clément: is it possible (1.3) to put o/

17 Teacher:

18 Clément: Bags

19 Teacher: In the class

20 Clément: In the class

(Irène, level 3) 
This example illustrates Irène's assertion in interview regarding the difficulty of eliciting L2 production from rather passive learners, showing that she does indeed 'always try to flip that coin to get them to ask questions' although 'it's not an easy thing.'

\section{Discussion and conclusions}

We begin Section VI with a summary of the main findings. In response to the first research question concerning the treatment of L2 English in secondary school EFL textbooks in France, we found that input was rather limited: examples occurred in only a small fraction of textbook activities, they were more likely to feature requests than focus explicitly on them, and their frequency decreased with the proficiency level targeted. More than half of all requests in French textbooks were direct requests, unlike previous studies of German or Spanish materials discussed earlier, and also unlike the requests actually produced by the French learners, who made proportionally fewer direct requests with increasing age/proficiency (Siddiqa, 2018). Metalinguistic input was limited, particularly with respect to sociopragmatic dimensions, and often centred on the use of lexicogrammatical elements such as particular modal verbs rather than the teaching of pragmatics. Our study confirms that the metapragmatic input is not only not sufficient but also is not pragmatically authentic for making polite L2 requests (Blum-Kulka et al., 1989; Brown \& Levinson, 1987), being direct in majority of the cases, with little modification to attenuate the imposition of the request.

Our second research question concerned interactional opportunities, specifically for making L2 English requests in secondary school classes. We particularly wanted to know what kind of support teachers offered pupils to make requests in English. Here again our results show a very low incidence of request behaviour, with an average of only 2 requests in English per 50-minute EFL lesson. While more learner requests were observed at level 1 , there was also a great deal of variation across teachers in their willingness to elicit or support L2 English requests by their pupils. This variation is explained in the analysis of beliefs and objectives with respect to textbooks and L2 pragmatic instruction which was the object of our third research question. First, with respect to teacher beliefs expressed in video-stimulated recall interview, our results highlighted an interesting paradox concerning the place of pragmatics in instructional programmes. Several lower secondary teachers (levels 1 and 2) believed their learners lacked the L2 proficiency required to interact spontaneously, and that it was 'too soon' to address pragmatic competence. The majority of upper secondary teachers (level 3), on the other hand, felt pragmatics lay outside their core concerns in an examination-driven syllabus and should be addressed earlier if at all. While most teachers claimed to espouse the action-oriented or task-based approaches encouraged in official programmes based on the CEFR, it was apparent both from classroom films and teacher interviews that the intrinsic value of meaning-focused interaction and the instructional goal of fostering communicative competence in L2 was not a given for all the teachers in our study. Many teachers habitually switched to L1 French for classroom management and for most interaction not directly related to lesson content, and even for instructions to launch different teaching activities. Several teachers also cited low proficiency and motivation among learners as reasons for limiting learnerlearner interaction in favour of teacher-fronted work at the board. 
The third research question on teachers' beliefs and objectives with respect to textbooks and L2 pragmatic instruction concerned the effect of teacher attitudes on opportunities to make L2 requests in class. Our analysis of the metapragmatic input which teachers provided to their pupils shows how differences in teaching objectives and strategies among our 10 teachers appear to have contributed to the presence or absence of request sequences. In classes where no English metapragmatic input related to requests was provided (Alice, Fanny, Hélène and Julie), the teachers generally thought their learners were not able to complete this speech act in the target language, or that it was not useful for them to do so. At levels 1 and 2 these teachers often taught very structured teacher-centred and teacher-controlled lessons and thought their pupils were not proficient enough to speak spontaneously; at level 3 they questioned the relevance of pragmatics to curricular goals and their own ability to teach it. A second subset of teachers (Birgit, Candice, and Giselle) provided impromptu metapragmatic input on request routines without deviating from planned activities. Here learners had a brief opportunity to reformulate an L1 request in the target language in a meaning-focused episode where their goal was to obtain permission for something (e.g. clean the board or hear an audio recording once more). However, the majority of L2 requests during classroom interaction occurred in our films of only three teachers, Danièle at level 1, Eva at level 2, and Irène at level 3. As we saw in Section V, these teachers had different levels of experience and showed similar variation in their views of textbooks, teaching philosophy, and choice of classroom activities to the other practitioners. All, however, were teaching classes which had on average lower proficiency than others at that level, suggesting pragmatic instruction may perhaps be considered more relevant with such learners.

In the case of Danièle and Irène, three additional features seem to separate the L2 request sequences in these teachers' classes from the others. First was their willingness to exploit any opportunity for meaningful negotiation in the target language, whether learners needed to borrow a tissue or leave belongings in the classroom. Second, they both persevered in scaffolding rather complex interactions where initial learner formulations were either entirely in L1, or very far from targetlike, and where the appropriate utterance required structures which appeared far beyond the learners' current competence. The teachers were skilled in immediately choosing an appropriate target, pausing to allow learners time to attempt this target, and then providing ongoing scaffolding until an acceptable request was produced or repeated. Finally, both teachers used English beyond the actual content of planned lessons after the start and before the end of lessons: Danièle organized little birthday celebrations and Irène negotiated practical arrangements after class, in each case actively creating more opportunities for pragmatic input and output in English.

This study serves to confirm, in the French secondary school context, previous findings concerning the limited pragmatic input available in textbooks. We show that teachers cannot rely on textbooks, in spite of supposed close links with the CEFR, and argue that without instructional input learners are unlikely to develop L2 pragmatic competence (Bardovi-Harlig \& Mahan-Taylor, 2003; Taguchi, 2015). In extending the purview of our investigation to classroom practice and teacher variables, we demonstrate how the problem of reliance on textbooks which lack representative language and discourse models can be compounded by an exam-driven syllabus which leaves little room for dealing 
with other linguistic challenges, and, in some cases, teachers' reluctance to teach this dimension of the target language

The primary limitation of our study is that it focuses on one speech act only, L2 English requests and on sources of metapragmatic input in classroom settings, that is, via textbooks and teachers. It thus offers reasons for learners' limited pragmatic development only with respect to request production (Siddiqa, 2018). We also acknowledge a potential effect of the observer's paradox, since all classes were filmed by the first author, although teachers claimed that they forgot about the camera after the first few minutes of recording. Future research should explore other speech acts such as agreements and disagreements which frequently occur in classroom setting as compared to other speech acts particularly at upper secondary level where students have more interactional opportunities in class.

We conclude that the limited ILP development observed in our larger study (Author, 2018) is linked to limited learning opportunities, either in textbooks or in terms of teacher priorities, confirming previous results in other teaching contexts. Our findings lend weight to calls to bridge the gap between research and classroom pedagogy (BardoviHarlig, 2020; Sykes, 2013), and highlight the need to support teachers in focusing on this importance aspect of communicative competence. We believe that the inclusion of pragmatics in formal examinations along with other communicative competence skills might encourage teachers to create more opportunities to learn ILP in class. The contribution of this article is to use data on teacher perspectives on ILP teaching and learning in combination with classroom interaction data in order to identify relevant attitudes and teaching styles which correlate with greater willingness to engage with L2 requests. These findings should serve to inform both material developers and ongoing pre-service and continuing teacher education in order to find ways to better integrate pragmatics in the FL classrooms.

\section{Funding}

The author(s) disclosed receipt of the following financial support for the research, authorship, and/ or publication of this article: The first author received funding from Erasmus Mundus Mobility with Asia (EMMA) programme (2013-2016) for her doctoral studies and this article is a part of her doctoral dissertation (Siddiqa, 2018).

\section{ORCID iDs}

Aisha Siddiqa (iD https://orcid.org/0000-0003-4481-0243

Shona Whyte (iD https://orcid.org/0000-0002-6739-1582

\section{Supplemental material}

Supplemental material for this article is available online.

\section{References}

Achiba, M. (2003). Learning to request in a second language: Child interlanguage pragmatics. Multilingual Matters. 
Alcón Soler, E. (2007). Fostering EFL learners' awareness of requesting through explicit and implicit consciousness-raising tasks. In Mayo, G. (Ed.), Investigating tasks in formal language learning (pp. 221-241). Multilingual Matters.

Al-Gahtani, S., \& Roever, C. (2013). 'Hi doctor, give me handouts': Low-proficiency learners and requests. ELT Journal, 67, 413-424.

Al-Gahtani, S., \& Roever, C. (2018). Proficiency and preference organization in second language refusals. Journal of Pragmatics, 129, 140-153.

Arva, V., \& Medgyes, P. (2000). Native and non-native teachers in the classroom. System, 28, $355-372$.

Baleghizadeh, S., \& Rastin, H. (2015). Investigating metapragmatic information in language teachers' books: A case of top notch. International Journal of Society, Culture and Language, $3,47-56$.

Bardovi-Harlig, K. (2001). Evaluating the empirical evidence: Grounds for instruction in pragmatics? In Rose, K.R., \& G. Kasper (Eds.), Pragmatics in language teaching (pp. 33-60). Cambridge University Press.

Bardovi-Harlig, K. (2020). Pedagogical linguistics: A view from L2 pragmatics. Pedagogical Linguistics, 1, 44-65.

Bardovi-Harlig, K., \& Griffin, R. (2005). L2 pragmatic awareness: Evidence from the ESL classroom. System, 33, 401-415.

Bardovi-Harlig, K., \& Hartford, B.S. (2005). Interlanguage pragmatics: Exploring institutional talk. Routledge.

Bardovi-Harlig, K., \& Mahan-Taylor, R. (Eds.) (2003). Teaching pragmatics. United States Department of State.

Barron, A. (2007). 'Ah no honestly we're okay': Learning to upgrade in a study abroad context. Intercultural Pragmatics, 4, 129-166.

Barron, A. (2016). Developing pragmatic competence using EFL textbooks: Focus on requests. Literacy Information and Computer Education Journal (LICEJ), 7, 2172-2179.

Blood, R.M. (2018). 'When you speak to a police officer and you refer to them as $d u$ ': The development of intercultural and pragmatic competence in Australian foreign language students on short-term study abroad in Germany. Unpublished doctoral dissertation, The University of Western Australia, Perth, WA, Australia.

Blum-Kulka, S., House, J., \& Kasper, G. (1989). Investigating cross-cultural pragmatics: An introductory overview. In Blum-Kulka, S. (Ed.), Cross-cultural pragmatics: Requests and apologies: Volume XXXI (pp. 1-36). Albex.

Borg, S. (2009). English language teachers' conceptions of research. Applied Linguistics, 30, $355-388$.

Borg, S. (2015). Teacher cognition and language education: Research and practice. Bloomsbury.

Brown, P., \& Levinson, S. (1987). Politeness: Some universals in language use. Cambridge University Press.

Celce-Murcia, M. (2008). Rethinking the role of communicative competence in Language Teaching. In Alcón Soler, E., \& M.P. Safont Jordà (Eds.), Intercultural language use and language learning (pp. 41-57). Springer.

Cohen, A.D. (2018). Learning pragmatics from native and nonnative language teachers. Multilingual Matters.

Cohen, A.D., \& Ishihara, N. (2013). Pragmatics. In Tomlinson, B. (Ed.), Applied linguistics and materials development. Bloomsbury Academic.

Cohen, A.D., \& Sykes, J.M. (2012). Strategy-based learning of pragmatics for intercultural education. In Dervin, F., \& A. Liddicoat (Eds.), Linguistics for intercultural education in language learning and teaching (pp. 87-111). John Benjamins. 
Corder, S.P. (1967). The significance of learners' errors. International Review of Applied Linguistics in Language Teaching, 5, 161-170.

Council of Europe. (2001). Common European Framework of Reference for Languages: learning, teaching, assessment. Council of Europe.

Council of Europe. (2018). Common European Framework of Reference for Languages: Learning, teaching, assessment: Companion volume with new descriptors. Council of Europe.

Crawford, J. (2002). The role of materials in the language classroom: Finding the balance. In Richards, J.C., \& W.A. Renandya (Eds.), Methodology in language teaching (pp. 80-91). Cambridge University Press.

Derakhshan, A., \& Eslami, Z.R. (2020). The effect of metapragmatic awareness, interactive translation, and discussion through video-enhanced input on EFL learners' comprehension of implicature. Applied Research on English Language, 9, 637-664.

Félix-Brasdefer, J.C. (2008). Perceptions of refusals to invitations: Exploring the minds of foreign language learners. Language Awareness, 17, 195-211.

Firth, A., \& Wagner, J. (2007). Second/foreign language learning as a social accomplishment: Elaborations on a reconceptualized SLA. The Modern Language Journal, 91, 800-819.

Glaser, K. (2017). Metapragmatic perceptions in native language vs. lingua franca settings: Does target language status during study abroad make a difference? Study Abroad Research in Second Language Acquisition and International Education, 2, 107-131.

Hadley, G. (2017). Grounded theory in applied linguistics research: A practical guide. Routledge.

Hassall, T. (2013). Pragmatic development during short-term study abroad: The case of address terms in Indonesian. Journal of Pragmatics, 55, 1-17.

Hernandez, T. (2010). The relationship among motivation, interaction, and the development of second language oral proficiency in a study-abroad context. The Modern Language Journal, 94, 600-617.

Hernandez, T., \& Boero, P. (2018). Explicit instruction for request strategy development during short-term study abroad. Journal of Spanish Language Teaching, 5, 35-49.

Ishihara, N. (2010). Instructional pragmatics: Bridging teaching, research, and teacher education. Language and Linguistics Compass, 4, 938-953.

Jefferson, G. (1984). Transcription notation. In Atkinson, J., \& J. Heritage (Eds.), Structures of social interaction. Cambridge University Press.

Kasper, G. (1992). Pragmatic transfer. Second Language Research, 8, 203-231.

Kasper, G. (1997). Can pragmatic competence be taught? (NetWork \#6) [HTML document]. University of Hawai'i, Second Language Teaching \& Curriculum Center.

Kasper, G., \& Rose, K.R. (2002). Pragmatic development in a second language. Blackwell.

Koike, D.A., \& Pearson, L. (2005). The effect of instruction and feedback in the development of pragmatic competence. System, 33, 481-501.

Lightbown, P.M., \& Spada, N. (2013). How languages are learned. 4th edition. Oxford University Press.

Limberg, H. (2015). Teaching how to apologize: EFL textbooks and pragmatic input. Language Teaching Research, 20, 700-718.

Martínez-Flor, A. (2008). The effects of an inductive-deductive teaching approach to develop learners' use of request modifiers in the EFL classroom. In Alcón Soler, E. (Ed.), Learning how to request in an instructed language learning context (pp. 191-225). Peter Lang.

Martínez-Flor, A., Guerra, A.F., \& Juan, E.U. (2003). Pragmatic competence and foreign language teaching. Publicacions de la Universitat Jaume I.

McConachy, T. (2017). Developing intercultural perspectives on language use: Exploring pragmatics and culture in foreign language learning. Multilingual Matters. 
Nguyen, T.T.M., \& Le Ho, G.A. (2018). Pragmatic development in the study abroad context: Impact of a cross-cultural pragmatic strategies intervention. In Walker, I., Daniel, K.G.C., Nagami, M., \& C. Bourguignon (Eds.), New perspectives on the development of communicative and related competence in foreign language education (pp. 239-288). De Gruyter Mouton.

Ogiermann, E. (2010). Teaching politeness with Green Line New? In Engelhardt, M., \& W. Gehring (Ed.), Fremdsprachendidaktik: Neue Aspekte in Forschung und Lehre (pp. 117134). Bis Verlag.

Ren, W., \& Han, Z. (2016). The representation of pragmatic knowledge in recent ELT textbooks. ELT Journal, 70, 424-434.

Rose, K.R. (2005). On the effects of instruction in second language pragmatics. System, 33, 385399.

Rose, K.R. (2009). Interlanguage pragmatic development in Hong Kong, phase 2. Journal of Pragmatics, 41, 2345-2364.

Rose, K.R., \& Kasper, G. (Eds.) (2001). Pragmatics in language teaching. Cambridge University Press.

Savignon, J.S. (1976). On the other side of the desk: A look at teacher attitudes and motivation in second-language learning. The Canadian Modern Language Review, 32, 295-302.

Savvidou, C., \& Economidou-Kogetsidis, M. (2019). Teaching pragmatics: Nonnative speaker teachers' knowledge, beliefs and reported practices. Intercultural Communication Education, $1,39-58$.

Schmidt, R. (1993). Consciousness, learning and interlanguage pragmatics. In Kasper, G., \& S. Blum-Kulka (Eds.), Interlanguage pragmatics (pp. 21-42). Oxford University Press.

Searle, J.R. (1976). A classification of illocutionary acts. Language in Society, 5, 1-23.

Shively, R. (2011). L2 pragmatic development in study abroad: A longitudinal study of Spanish service encounters. Journal of Pragmatics, 43, 1818-1835.

Siddiqa, A. (2018). The use and acquisition of politeness strategies among EFL learners in France: An exploratory study of interlanguage pragmatic development [Doctoral dissertation]. Université Nice Sophia-Antipolis.

Sykes, J.M. (2013). Multiuser virtual environments: Learner apologies in Spanish. In Taguchi, N., \& J.M. Sykes (Eds.), Technology in interlanguage pragmatics research and teaching. John Benjamins.

Sykes, J.M. (2017). Technologies for teaching and learning intercultural competence and interlanguage pragmatics. In Chapelle, C.A., \& S. Sauro (Eds.), The handbook of technology and second language teaching and learning (pp. 118-133). John Wiley and Sons.

Syrbe, M., \& Rose, H. (2016). An evaluation of the global orientation of English textbooks in Germany. Innovation in Language Learning and Teaching, 12, 152-163.

Szczepaniak-Kozak, A., \& Wąsikiewicz-Firlej, E. (2018). Pragmatic competence of teachers: A contrastive case study of native and non-native teachers of English. Applied Linguistics Papers, 25, 127-142.

Taguchi, N. (2015). Instructed pragmatics at a glance: Where instructional studies were, are, and should be going. Language Teaching, 48, 1-50.

Taguchi, N. (2018). Data collection and analysis in developmental L2 pragmatics research. In Gudmestad, A., \& A. Edmonds (Eds.), Critical reflections on data in second language acquisition (pp. 7-32). John Benjamins.

Taguchi, N., \& Sykes, J.M. (2013). Technology in interlanguage pragmatics research and teaching. John Benjamins.

Tateyama, Y. (2001). Explicit and implicit teaching of pragmatic routines: Japanese sumimasen. In Rose, K.R., \& G. Kasper (Eds.), Pragmatics in language teaching (pp. 200-222). Cambridge University Press. 
Usó-Juan, E. (2008). The presentation and practice of the communicative act of requesting in textbooks: Focusing on modifiers. In Alcón Soler, E., \& M.P. Safont Jordà (Eds.), Intercultural language use and language learning (pp. 223-243). Springer.

Vellenga, H. (2004). Learning pragmatics from ESL \& EFL textbooks: How likely? TESL-EJ, 8. Available at: http://www.tesl-ej.org/wordpress/issues/volume8/ej30/ej30a3 (accessed November 2021).

Wagner, J., \& Firth, A. (1997). Communication strategies at work. In Kasper, G., \& E. Kellerman (Eds.), Communication strategies: Psycholinguistic and sociolinguistic perspectives (pp. 323-344). Longman. 